\title{
Screening transferable microsatellite markers across genus Phalaenopsis (Orchidaceae)
}

\author{
Ya-Zhu Ko ${ }^{1}$, Huei-Chuan Shih² ${ }^{2}$ Chi-Chu Tsai ${ }^{3,4}$, Hsing-Hua Ho ${ }^{1}$, Pei-Chun Liao ${ }^{5^{*}}$ and Yu-Chung Chiang ${ }^{1,6^{*}}$ (1)
}

\begin{abstract}
Background: Molecular identification based on microsatellite loci is an important technology to improve the commercial breeding of the moth orchid. There are more than 30,000 cultivars have been enrolled at the Royal Horticultural Society (RHS). In this study, genomic microsatellite primer sets were developed from Phalaenopsis aphrodite subsp. formosana to further examine the transferability of across 21 Phalaenopsis species.

Methods and results: Twenty-eight polymorphic microsatellite markers were obtained using the magnetic bead enrichment method, with high transferability of the 21 species of the genus Phalaenopsis, especially in the subgenus Phalaenopsis. The 28 newly developed polymorphic microsatellite markers with high polymorphism information content values. The best and second fit grouping $(K)$ are inferred as two and four by the $\Delta K$ evaluation in the assignment test. This result indicates that these microsatellite markers are discernible to subgenus Phalaenopsis.

Conclusions: Our results indicate that these new microsatellite markers are useful for delimiting species within genus Phalaenopsis. As expected, the genetic relationships between species of subgenus Phalaenopsis can be well distinguished based on the assignment test. These molecular markers could apply to assess the paternity of Phalaenopsis as well as investigating hybridization among species of genus Phalaenopsis.
\end{abstract}

Keywords: Phalaenopsis, Microsatellites, Polymorphism, Transferability

\section{Background}

The subtropical Taiwan Island that is situated off the southeastern Asian continent has well-suited climate conditions for the growth of orchids. Since the high quality of breeding and micropropagation technology coupled with market demands of the orchid genus Phalaenopsis Blume (Orchidaceae), Taiwan has become one of the important exporting countries of orchids in the world (Chen and Chen 2007, 2011; Tang and Chen 2007). The genus Phalaenopsis belongs to the family Orchidaceae, subfamily Epidendroideae, tribe Vandeae and subtribe Aeridinae (Dressler 1993), which is often known

\footnotetext{
${ }^{*}$ Correspondence: pcliao@ntnu.edu.tw; yuchung@mail.nsysu.edu.tw ${ }^{1}$ Department of Biological Sciences, National Sun Yat-sen University, Kaohsiung 804, Taiwan

${ }^{5}$ Department of Life Science, National Taiwan Normal University, Taipei, Taiwan

Full list of author information is available at the end of the article
}

as moth orchid and comprises approximately 66 species (Christenson 2001). Phalaenopsis species is broadly distributed across Himalayas of northern India, South India, Sri Lanka, Southeast China, Taiwan, Indonesia, Thailand, Myanmar, Malaysia, the Philippines, Papua New Guinea and northeastern Australia (Chen and Chen 2011; Christenson 2001). According to the pollinia numbers (Christenson 2001) and molecular evidences (Tsai et al. 2010), Phalaenopsis can be divided into five subgenera: the four pollinia clades of subgenera Proboscidioides, Aphyllae, and Parishianae and the two pollinium clades of subgenera Polychilos and Phalaenopsis. Among these subgenera, the Polychilos and Phalaenopsis was each subdivided into four sections Polychilos, Fuscatae, Amboinenses, Zebrinae and Phalaenopsis, Deliciosae, Esmeralda, Stauroglottis, respectively (Dressler 1993; Christenson 2001).

The species of genus Phalaenopsis are most popular epiphytic monopodial orchids for their distinctive and 
varied flowers with the unique structure. Horticultural breeding by hybridization remixed floral characters, such as the colors, shapes, and sizes, to create diversified varieties and cultivars. Based on the high breeding and cultivation techniques for the regulation of light and feeding and the development in interspecific and intergeneric hybrids breeding and polyploidy, improvement of the long-lasting quality of the floral traits made Phalaenopsis as one of an important orchid source for cut-flower crop.

There are two indigenous species of Phalaenopsis native to Taiwan, the P. aphrodite subsp. formosana and P. equestris (Chen and Wang 1996). Both species were classified as the section Phalaenopsis (Christenson 2001). Phalaenopsis aphrodite subsp. formosana, commonly known as the Taiwan moth orchid, has been widely used as an important breeding hybrids parent, and it is one of the most important progenitors for the traits of modern large and white of floral organs commercial hybrids breeding (Tanaka et al. 2005). Phalaenopsis equestris is another important breeding parent for the miniature type of multi-flowers and artificial hybrids with white petals and sepals and a red lip (Men et al. 2003; Tang and Chen 2007).

Recently, intergeneric hybrids between Phalaenopsis and Ascocenda cultivars were developed to introduce orange color into hybrid cultivars (Liu et al. 2016). However, complex phenotype and long stage of juvenile make the identification of varieties and cultivars of Phalaenopsis plants difficult and time consuming. In addition, traditional horticultural breeding technique for new cultivars of Phalaenopsis by integrating the morphology, physiological development, and environmental factors as well as their complex interactions makes the breeding consequence unpredictable and uncertain. Molecular markers can provide sensitive and accurate tools for identifying species and cultivars. Therefore, development of highly reliable, rapid, and cheap technique for differentiating and identifying seedlings of species and cultivars of Phalaenopsis is necessary and useful for enhancing the efficiency of the breeding. Furthermore, development of molecular markers could apply to paternity analysis, phylogenetic reconstruction, and resolving long-standing issues on Phalaenopsis breeding. Microsatellite markers with characteristics of high level of polymorphism, codominant inheritance and reproducibility (Powell et al. 1996) are useful tools for application in plant genetics and crop breeding, including fruit tree (Chiang et al. 2012; Chiou et al. 2012; Tsai et al. 2013; Lai et al. 2015) and orchid (Tsai et al. 2014, 2015). Compared to previous studies (Sukma 2011; Tsai et al. 2015), we intend to use more microsatellite loci as well as more extensive species testing in this study to enhance the discriminatory power between Phalaenopsis genus.
The genome size is small for $P$. aphrodite subsp. formosana (Hsiao et al. 2011) and roughly $2.81 \mathrm{pg}$ in diploid genome (Chen et al. 2013), which is suitable for the development of microsatellite markers. Here, the objective of this study was to develop transferable microsatellite markers from $P$. aphrodite subsp. formosana using the modified magnetic bead enrichment method. Based on these transferable markers, the molecular identification systems is able to be established for accessing the hybridization and introgression among species of the genus Phalaenopsis in future work.

\section{Materials and methods \\ Plant materials}

There are 21 species of the genus Phalaenopsis comprised of five subgenera used in this study. The taxonomy and nomenclature are followed (Christenson 2001), and specimens information are listed in Table 1. All samples were collected from the plants planted in the greenhouse at the Kaohsiung District Agricultural Improvement Station (KDAIS) in Taiwan by C. C. Tsai. Voucher specimens were deposited in herbarium of the National Museum of Natural Science, Taiwan (TNM).

\section{Screening, sequencing microsatellite loci, and primer designation}

Total DNA was extracted from tissue culture seedlings or young leaves following the procedure by a Plant Genomic DNA Extraction Kit (RBC Bioscience, Taipei, Taiwan). The DNA sample from $P$. aphrodite subsp. formosana was screened for microsatellites by digested with the restriction enzyme MseI (Promega, Madison, Wisconsin, USA) and confirmed with $1.5 \%$ agarose gel electrophoresis. The digested fragment sizes with a range from 400 to $1000 \mathrm{bps}$ were extracted using agarose gel and then ligated with $M s e I$-adapter pair (5'-TACTCAGGACTC AT- $3^{\prime}$ and $5^{\prime}$-GACGATGAGTCCTGAG- $3^{\prime}$ ) using DNA T4 ligase. As the template DNA for the enrichment of the partial genomic library, the ligated products were then used to perform 20 cycles of pre-hybridization PCR amplification in a $20 \mu \mathrm{L}$ reaction mixture using the adapter specific primer (MseI-N: 5'-GATGAGTCCT GAGTAAN-3'). The PCR mixture contained 20 ng template DNA, 10 pmol MseI-N, $2 \mu \mathrm{L} 10 \times$ reaction buffer, $2 \mathrm{mM}$ dNTP mix, $2 \mathrm{mM} \mathrm{MgCl}$, $0.5 \mathrm{U}$ Taq DNA polymerase (Promega), and sterile water was added to total volume of $20 \mu \mathrm{L}$, with the PCR program of initial denaturation of $94{ }^{\circ} \mathrm{C}$ for $5 \mathrm{~min}$, followed by 18 cycles of $30 \mathrm{~s}$ at $94{ }^{\circ} \mathrm{C}, 1 \mathrm{~min}$ at $53{ }^{\circ} \mathrm{C}, 1 \mathrm{~min}$ at $72{ }^{\circ} \mathrm{C}$, and a final extension at $72^{\circ} \mathrm{C}$ for $10 \mathrm{~min}$ using a Labnet MultiGene 96-well Gradient Thermal Cycler (Labnet, Edison, New Jersey, USA). The biotinylated oligonucleotide repeat probes $(\mathrm{AG})_{15},(\mathrm{AC})_{15},(\mathrm{TCC})_{10}$, and (TTG) $)_{10}$ were used 
Table 1 Information on geographic distribution, species code and voucher specimens of the genus Phalaenopsis used in this study

\begin{tabular}{|c|c|c|c|}
\hline Classification & Geographical distribution & Code & Source $^{a}$ \\
\hline \multicolumn{4}{|c|}{ Subgenus Proboscidioides (Rolfe) E. A. Christ. } \\
\hline P. lowii Rchb.f. & Myanmar, and adjacent western Thailand & P4 & KDAIS-KC88 \\
\hline \multicolumn{4}{|c|}{ Subgenus Aphyllae (Sweet) E. A. Christ. } \\
\hline P. minus (Seidenf.) E. A. Christ. & Endemic to Thailand & P11 & KDAIS-KC227 \\
\hline $\begin{array}{l}\text { P. braceana (J. D. Hook.) E. A. } \\
\text { Christ. }\end{array}$ & Bhutan and China & P13 & KDAIS-KC289 \\
\hline \multicolumn{4}{|c|}{ Subgenus Parishianae (Sweet) E. A. Christ. } \\
\hline P. parishii Rchb.f. & Eastern Himalayas, India, Myanmar, and Thailand & P15 & KDAIS-KC316 \\
\hline \multicolumn{4}{|c|}{ Subgenus Polychilos (Breda) E. A. Christ. } \\
\hline P. mannii Rchb.f. & Northeast India, Nepal, and China to Vietnam & P18 & KDAIS-KC22 \\
\hline $\begin{array}{l}\text { P. cornu-cervi (Breda) Bl. and } \\
\text { Rchb.f. }\end{array}$ & Northeast India and the Nicobar Islands to Java and Borneo & P2 & KDAIS-KC23 \\
\hline P. kunstleri J. D. Hook. & Myanmar and Malay Peninsula & P8 & KDAIS KC-139 \\
\hline P. pulchra (Rchb.f.) Sweet & Endemic to the Philippines (Luzon and Leyte) & P1 & KDAIS-KC17 \\
\hline P. violacea Witte & Indonesia (Sumatra) and Malaysia (Malay Peninsula) & P9 & KDAIS-KC153 \\
\hline P. micholitzii Rolfe & Philippines (Mindanao) & P19 & KDAIS-KC382 \\
\hline P. maculata Rchb.f. & Malaysia (Pahang), East Malaysia (Sabah and Sarawak), and Indonesia (Kalimantan Timur) & P3 & KDAIS-KC49 \\
\hline P. amboinensis J. J. Sm. & Indonesia (Molucca Archipelago and Sulawesi) & P17 & KDAIS-KC157 \\
\hline P. inscriptiosinensis Fowlie & Endemic to Indonesia (Sumatra) & P14 & KDAIS-KC298 \\
\hline P. corningiana Rchb.f. & Borneo (Sarawak and elsewhere on the island) & P16 & KDAIS-KC346 \\
\hline \multicolumn{4}{|l|}{ Subgenus Phalaenopsis } \\
\hline P. amabilis (L.) Blume & $\begin{array}{l}\text { Widespread from Sumatra and Java to the southern Philippines, east to New Guinea and } \\
\text { Queensland, Australia }\end{array}$ & P5 & KDAIS-KC23 \\
\hline P. aphrodite Rchb.f. & Northern Philippines and southeastern Taiwan & PN & KDAIS-KC96 \\
\hline P. schilleriana Rchb.f. & Endemic to the Philippines & P10 & KDAIS-KC429 \\
\hline P. chibae Yukawa & Yukawa endemic to Vietnam & P20 & KDAIS-KC488 \\
\hline P. pulcherrima (Lindl.) J. J. Sm. & $\begin{array}{l}\text { Widespread from northeast India and southern China throughout Indochina to Malaysia } \\
\text { (Malay Peninsula), Indonesia (Sumatra), and East Malaysia (Sabah) }\end{array}$ & P12 & KDAIS-KC256 \\
\hline P. equestris (Schauer) Rchb.f. & Philippines and Taiwan & P7 & KDAIS-KC203 \\
\hline P. lindenii Loher & Endemic to the Philippines & P6 & KDAIS-KC119 \\
\hline
\end{tabular}

a Plant materials were cultivated at the Kaohsiung District Agricultural Improvement Station, Taiwan and voucher specimens were deposited at the herbarium of the National Museum of Natural Science, Taiwan

to hybridize with the amplicons at $68{ }^{\circ} \mathrm{C}$ for $1 \mathrm{~h}$. The hybridization mixture was then enriched using $1 \mathrm{mg}$ of streptavidin magnesphere paramagnetic particles (Promega) at $42{ }^{\circ} \mathrm{C}$ for $2 \mathrm{~h}$ and then eluted. Subsequently, DNA fragments containing microsatellites were purified and then amplified by 25 -cycle-PCR using purified captured DNA fragments as templates $(5 \mu \mathrm{L}), M s e \mathrm{I}-\mathrm{N}$ (10 pmol), $10 \times$ reaction buffer $(2 \mu \mathrm{L})$, dNTP mix $(2 \mathrm{mM})$, $\mathrm{MgCl}_{2}(2 \mathrm{mM}), 0.5 \mathrm{U}$ Taq DNA polymerase (Promega), and supplement sterile water to $20 \mu \mathrm{L}$ under the amplification conditions described above. The PCR products were purified by the HiYield ${ }^{\mathrm{TM}}$ Gel PCR DNA Fragments Extraction Kit (RBC Bioscience) and used for cloning. The purified DNA was ligated into the pGEM $^{\circledR}$-T Easy Vector System (Promega), and used to transformed into E. coli $\mathrm{DH} 5 \alpha$ competent cells. The positive clones were randomly selected and used for sequencing. In total, 321 positive colonies were collected and amplified with T7 and SP6 primers and sequenced on an ABI PRISM 3700 DNA Sequencer (Applied Biosystems, Foster City, California, USA). Sequences containing microsatellites were detected using Tandem Repeats Finder version 4.09 (Benson 1999), and primer pairs were designed for microsatellite loci with suitable flanking regions to amplify using FastPCR software version 6.5.94 (Kalendar et al. 2009). Each primer pairs were designed to amplify with a fragment in the range of $100-400 \mathrm{bp}$.

\section{Microsatellites PCR amplification}

To verify the effectiveness and polymorphisms of 28 microsatellite loci, all primer pairs designed for amplifying these microsatellites were tested using the $P$. 
aphrodite subsp. formosana DNA samples together with the other 20 Phalaenopsis species. The optimal annealing temperature was determined using gradient PCR on a Labnet MultiGene 96-well Gradient Thermal Cycler (Labnet). The PCR was carried out in a total reaction volume of $20 \mu \mathrm{L}$, in which the PCR reaction mixtures contained $20 \mathrm{ng}$ template DNA, $0.2 \mu \mathrm{M}$ forward and reverse primers, $2 \mu \mathrm{L} 10 \times$ reaction buffer, $2 \mathrm{mM}$ dNTP mix, $2 \mathrm{mM} \mathrm{MgCl}_{2}$, and $0.5 \mathrm{U}$ of Taq polymerase (Promega). The gradient PCR protocol was set at $94{ }^{\circ} \mathrm{C}$ for $5 \mathrm{~min}$, followed by 35 cycles of $94{ }^{\circ} \mathrm{C}$ for $40 \mathrm{~s}$, a temperature gradient $50-60{ }^{\circ} \mathrm{C}$ for $60 \mathrm{~s}, 72{ }^{\circ} \mathrm{C}$ for $60 \mathrm{~s}$, and a final step of $72{ }^{\circ} \mathrm{C}$ for $10 \mathrm{~min}$. Then, the PCR products were assessed using $10 \%$ polyacrylamide gel electrophoresis and stained with ethidium bromide and visualized (EtBr) under UV light exposure. The patterns and length of alleles were recorded digitally by Quantity One ver. 4.62 (Bio-Rad Laboratories, Hercules, California, USA).

\section{Data analyses}

In total, 146 repeatable amplicons with length variation were screened from 28 microsatellite primer pairs (Table 2) in 21 species (Table 1). The number and average of amplicons (alleles) per primer pairs and the polymorphism information content (PIC) value of each loci were estimated using Power-Marker version 3.25 (Liu and Muse 2005). The Bayesian clustering method was used to estimate genotyping group information and genetic components for 21 Phalaenopsis taxa with the assistance of STRUCTURE ver. 2.3.4 (Pritchard et al. 2000; Falush et al. 2003, 2007). The admixture model (Hubisz et al. 2009) was selected in the Bayesian clustering analysis. The posterior probability of the genetic grouping number $(\mathrm{K}=1-21)$ was estimated using the Markov chain Monte Carlo (MCMC) approach and 10 independent runs with a first $10 \%$ discarding (burnin) followed by 5,000,000 MCMC steps for each grouping number. The first-two best grouping numbers were evaluated using $\Delta \mathrm{K}$ process (Evanno et al. 2005) by STRUCTURE HARVESTER ver. 0.6.8 (Earl and vonHoldt 2012). The graphical display of the results was drawn by DISTRUCT program (Rosenberg 2004).

\section{Results and discussion}

All of 21 Phalaenopsis species reveal either zero, one or two PCR amplicons in each of 28 microsatellite loci. One or two PCR amplicons per locus represent homozygotes or heterozygotes, and no amplicon indicate lacking this homologous microsatellite locus (Table 2). The genome size of Phalaenopsis aphrodite subsp. formosana detected by flow cytometry reveals roughly $2.81 \mathrm{pg}$ in diploid genome (Chen et al. 2013) and all diploid species of Phalaenopsis have 38 chromosome number (Christenson
2001). These related studies and our current results indicate that 21 Phalaenopsis taxa studied are diploid plants, except the $P$. lowii and $P$. minus are not listed in the study of Chen et al. (Christenson 2001; Chen et al. 2013).

In total, 146 amplicons (alleles) were identified by 28 microsatellite primer pairs across 21 native Phalaenopsis species, and the number of amplicons per primer pairs ranged from 2 to 12, with an average of 5.21 (Table 2). The cross-species amplification test for the 20 other species was conducted using 28 microsatellite primers developed by $P$. aphrodite subsp. formosana, and the species of $P$. amabilis (L.) Blume, P. schilleriana Rchb.f, P. chibae, $P$. equestris (Schauer) Rchb.f. and P. lindenii Loher have higher transferable loci. The above mentioned four species with $P$. aphrodite subsp. formosana are all classified under the genus Phalaenopsis. The microsatellite primers could be successfully transferable to an average of 6.21 species [range from two (PA7, PA11 and PA41) to 20 (PA101) species] (Table 3). Due to the high transferability to species of the subgenus Phalaenopsis, these newly developed microsatellite primers are able to apply to establish a standard molecular identification operating system in Phalaenopsis.

The allelic polymorphism information content (PIC) values reflect the extent of allele diversity among the species, the PIC values in the present study ranged from 0.38 to 0.87 , with an average of 0.63 (Table 4). Previous studies showed that the PIC values ranged from 0.1754 to 0.6740 (Sukma 2011) and 0 to 0.682 (Tsai et al. 2015) for the genomic microsatellite loci and EST-SSR of Phalaenopsis species, respectively. Thus, the PIC value in our study is greater than previous studies on Phalaenopsis. This PIC result is consistent with genomic microsatellite studies in Scutellaria austrotaiwanensis (Hsu et al. 2009), mango (Chiang et al. 2012), and Indian jujube (Chiou et al. 2012).

For genetically delimiting 21 species of the genus Phalaenopsis, a model-based Bayesian clustering algorithm was performed in STRUCTURE 2.3.4. The result showed that the first two best clustering numbers are $K=2$ and $K=4$ (Table 4). The $\Delta K$ was 96.55 and 2.31 when $K=2$ and $K=4$ in the Bayesian clustering analysis, respectively. Under $K=2$, most species of the subgenus Phalaenopsis were assigned to the same cluster with high percent of Component 1 (pink segment in Fig. 1A) except $P$. pulcherrima that is genetically assigned to sections Esmeralda (subgenus Polychilos). The subgenus Proboscidioides, Aphyllae, and Parishianae, and Polychilos were consigned to the cluster with high percent of Component 2 (green segment in Fig. 1A) except $P$. kunstleri belonging to subgenus Polychilos which revealed an admixture genetic composition (56.8\% of Component 1 and $43.2 \%$ of Component 
Table 2 Characteristics of the 28 polymorphic microsatellite primers derived from Phalaenopsis aphrodite subsp. formosana

\begin{tabular}{|c|c|c|c|c|c|c|}
\hline Locus & Primer sequences $\left(5^{\prime}-3^{\prime}\right)$ & Repeat motif & Allelic size (bp) & Annealing temperature $\left({ }^{\circ} \mathrm{C}\right)$ & No. of alleles & PIC \\
\hline \multirow[t]{2}{*}{ PA5-1 } & F:TCCCATTATCACTCCCTCAC & $(\mathrm{TC})_{14}$ & $140-164$ & 59 & 4 & 0.67 \\
\hline & R: GGTTAGAGATATAGGGAGAG & & & & & \\
\hline \multirow[t]{2}{*}{ PA5-2 } & F: СТCTCTTTCCTTCTCACCTC & $(\mathrm{TC})_{10}$ & $98-104$ & 58 & 4 & 0.61 \\
\hline & R: AAGATAGAGGGAGAGAGTGG & & & & & \\
\hline \multirow[t]{2}{*}{ PA7 } & F: CTCTGCTTCTCACCTTTCAC & $(\mathrm{TC})_{12}$ & $116-264$ & 56 & 3 & 0.55 \\
\hline & R: GGACAGAAAGTGAGAGAGAG & & & & & \\
\hline \multirow[t]{2}{*}{ PA10 } & F:TCTTCAGTCCCTCACTCATC & $(\mathrm{CT})_{14}$ & $132-152$ & 58 & 7 & 0.75 \\
\hline & R: ACAAAGCGGTGGAGAATATG & & & & & \\
\hline \multirow[t]{2}{*}{ PA11 } & F: ATCTATTGCTCTTTGTCCTC & $(\mathrm{CT})_{42}$ & $214-216$ & 55 & 2 & 0.38 \\
\hline & R:TAGCAAAGAGATGCTGAAGG & & & & & \\
\hline \multirow[t]{2}{*}{ PA14 } & F:TTTTCACTCTCCCTCCATCC & $(\mathrm{CT})_{21}$ & $182-186$ & 52 & 3 & 0.55 \\
\hline & R: GATGTAGAGAATGAGGGAGC & & & & & \\
\hline \multirow[t]{2}{*}{ PA15 } & F:TCTCCTACTCCCTCTATCTCA & $(\mathrm{CT})_{25}$ & $306-310$ & 56 & 3 & 0.55 \\
\hline & R: CTTGAAAGGCAGAGAGATAG & & & & & \\
\hline \multirow[t]{2}{*}{ PA19 } & F:TCTCCCTATATCTCTGCATC & $(\mathrm{CTCC})_{4}$ & $154-158$ & 51 & 3 & 0.58 \\
\hline & R:TGGAAAGAGAAAGGTTCAGG & & & & & \\
\hline \multirow[t]{2}{*}{ PA21 } & F:TCTCTCACTTTGTCACTCGC & $(\mathrm{CT})_{14}$ & $134-146$ & 57 & 6 & 0.77 \\
\hline & R: AAAGGGAAGTAGGGAAGGAG & & & & & \\
\hline \multirow[t]{2}{*}{ PA24 } & F:TTGATCTCTCTGGCACCCAC & $(\mathrm{TC})_{36}$ & $216-224$ & 55 & 3 & 0.59 \\
\hline & R: AAGAGAGAGTTAGTTGGAGAT & & & & & \\
\hline \multirow[t]{2}{*}{ PA25-1 } & F: ACCCACTTTCTCCTATCTCC & $(\mathrm{CT})_{20}$ & $176-202$ & 58 & 5 & 0.64 \\
\hline & R: GATGAAAGAGAGTGAGAGCG & & & & & \\
\hline \multirow[t]{2}{*}{ PA25-2 } & F:TCTCCCTCTCTTTACCACTC & $(\mathrm{CT})_{12}$ & $92-267$ & 58 & 6 & 0.73 \\
\hline & R: GTGAGAGAGATAGAGTGAGC & & & & & \\
\hline \multirow[t]{2}{*}{ PA32-1 } & F: CTCTTCCTGCTTTTCCTAGG & $(\mathrm{CT})_{25}$ & $148-222$ & 57 & 8 & 0.83 \\
\hline & R: AAGAGGGTGTGAGGAAGAGG & & & & & \\
\hline \multirow[t]{2}{*}{ PA32-2 } & F:TCTCTCACTACTCTATCTTG & $(\mathrm{CT})_{18}$ & $140-152$ & 54 & 5 & 0.73 \\
\hline & R: GAGAAGATAGAAAGAGTGAG & & & & & \\
\hline \multirow[t]{2}{*}{ PA36 } & F: CTCCACTTTATCTCTCTACC & $(\mathrm{TC})_{39}$ & $220-250$ & 55 & 4 & 0.67 \\
\hline & R: ATTGAGCGAGATAAAACTAG & & & & & \\
\hline \multirow[t]{2}{*}{ PA37 } & F:TTTACCTCTTTTGCTAGCTC & $(\mathrm{TC})_{23}$ & $226-234$ & 50 & 4 & 0.67 \\
\hline & R: AAGAGAAAGGGAAGGAGAGC & & & & & \\
\hline \multirow[t]{2}{*}{ PA38 } & F: CTCTCTCACTCTATTACTCC & $(\mathrm{CT})_{32}$ & $224-384$ & 54 & 9 & 0.84 \\
\hline & R: AGCTAGATAGAGGGAGAAAG & & & & & \\
\hline \multirow[t]{2}{*}{ PA40 } & F: GAGCAACATTCACTAGAGAG & $(C A)_{14}$ & $258-320$ & 56 & 6 & 0.79 \\
\hline & R: CTGGCAAAGCTTTGAGAAGG & & & & & \\
\hline \multirow[t]{2}{*}{ PA41 } & F: GAGGAGAAATAATGATTCCG & $(A G)_{12}$ & $138-140$ & 50 & 2 & 0.38 \\
\hline & R: AGACACTCTCACACACTTTC & & & & & \\
\hline \multirow[t]{2}{*}{ PA63 } & F:TTCATTCCATCTACCCCATC & $(\mathrm{CT})_{8}$ & $130-136$ & 55 & 3 & 0.59 \\
\hline & R: GATAGAAAGACTAGAGTAGG & & & & & \\
\hline \multirow[t]{2}{*}{ PA64 } & F: CTCTCCTTTTTCTTATCTTTCAC & $(C T)_{94}$ & $248-296$ & 55 & 3 & 0.55 \\
\hline & R:TAGAGAGATAGAGGGCAAGC & & & & & \\
\hline PA74-1 & F: AATGACCTCTCTGCTCTCTC & $(\mathrm{TC})_{28}$ & $172-306$ & 50 & 3 & 0.59 \\
\hline & R: GCAAGAGAAGTTGTGGGATGG & & & & & \\
\hline PA74-2 & F: CATCCCACAACTTCTCTTGC & $(C T)_{13}$ & $122-134$ & 55 & 5 & 0.58 \\
\hline & R: AGTGCTCAAGCGAGTTAGAGAC & & & & & \\
\hline PA83-1 & F: CССTCTTTCTCTCATTGTCC & $(\mathrm{TC})_{9}$ & 190-198 & 54 & 2 & 0.35 \\
\hline & R: GGGACAGAGTGCATAAGATG & & & & & \\
\hline
\end{tabular}


Table 2 continued

\begin{tabular}{|c|c|c|c|c|c|c|}
\hline Locus & Primer sequences $\left(5^{\prime}-3^{\prime}\right)$ & Repeat motif & Allelic size (bp) & Annealing temperature $\left({ }^{\circ} \mathrm{C}\right)$ & No. of alleles & PIC \\
\hline \multirow[t]{2}{*}{ PA83-2 } & F: ССТTATCTCTTCTCTCTACC & $(\mathrm{TC})_{36}$ & $168-210$ & 50 & 12 & 0.87 \\
\hline & R: AGAAAGGAAGGGTAGGAGAG & & & & & \\
\hline \multirow[t]{2}{*}{ PA100-1 } & F:TCCCTCTATTTTAGACACCC & $(\mathrm{TC})_{11}$ & $132-136$ & 52 & 2 & 0.35 \\
\hline & R: GGAGAAAGAGCAAGACAGTG & & & & & \\
\hline \multirow[t]{2}{*}{ PA100-2 } & F:TCTCCATCCGTTAGCCTCTC & $(\mathrm{CT})_{16}$ & $128-136$ & 59 & 5 & 0.73 \\
\hline & R: GGGTAGGCAGAGAGAGTGAT & & & & & \\
\hline \multirow[t]{3}{*}{ PA101 } & F: CCCACTCACACTCTATCTTC & $(\mathrm{TC})_{11}$ & $126-138$ & 55 & 7 & 0.63 \\
\hline & R: AGGGTCAAACAGAATGAAGG & & & & & \\
\hline & & & & Average & 4.57 & 0.63 \\
\hline
\end{tabular}

Table 3 The result of the 28 polymorphic microsatellite loci isolated from Phalaenopsis aphrodite subsp. formosana test on 21 samples

\begin{tabular}{|c|c|c|c|c|c|c|c|c|c|c|c|c|c|c|c|c|c|c|c|c|c|c|}
\hline Locus & PN & P1 & P2 & P3 & P4 & P5 & P6 & P7 & P8 & P9 & P10 & P11 & P12 & P13 & P14 & P15 & P16 & P17 & P18 & P19 & P20 & IS \\
\hline PA5-1 & 0 & - & - & 0 & - & 0 & 0 & 0 & 0 & - & - & - & - & - & - & - & - & - & - & - & - & 6 \\
\hline PA5-2 & 0 & - & - & - & - & 0 & 0 & - & 0 & - & $E$ & - & - & - & - & - & - & - & - & - & - & 5 \\
\hline PA7 & $E$ & - & - & - & - & - & 0 & - & - & - & - & - & - & - & - & - & - & - & - & - & - & 2 \\
\hline PA10 & 0 & 0 & 0 & $E$ & - & $E$ & 0 & $E$ & - & - & 0 & - & 0 & - & - & - & 0 & - & 0 & - & 0 & 12 \\
\hline PA11 & 0 & - & - & - & - & - & - & - & - & - & 0 & - & - & - & - & - & - & - & - & - & - & 2 \\
\hline PA14 & 0 & - & - & - & - & - & 0 & 0 & - & - & 0 & - & - & - & - & - & - & - & - & - & - & 4 \\
\hline PA15 & 0 & - & - & - & - & - & - & 0 & - & - & 0 & - & - & - & - & - & - & - & - & - & 0 & 4 \\
\hline PA19 & 0 & - & - & - & - & 0 & 0 & 0 & 0 & - & 0 & - & - & - & 0 & - & - & - & - & - & 0 & 8 \\
\hline PA21 & 0 & - & 0 & 0 & 0 & 0 & 0 & 0 & 0 & - & $E$ & 0 & - & - & 0 & - & - & - & - & - & - & 11 \\
\hline PA24 & 0 & - & - & - & - & 0 & 0 & - & - & - & - & - & - & - & - & - & - & - & - & - & - & 3 \\
\hline PA25-1 & 0 & - & - & - & - & 0 & 0 & 0 & - & - & - & - & - & - & - & 0 & 0 & - & $E$ & - & 0 & 8 \\
\hline PA25-2 & 0 & - & - & - & - & - & - & $E$ & - & - & 0 & $E$ & - & - & - & - & - & - & $E$ & - & - & 5 \\
\hline PA32-1 & $E$ & - & - & - & - & - & 0 & 0 & 0 & - & 0 & - & - & - & - & - & 0 & - & - & 0 & 0 & 8 \\
\hline PA32-2 & 0 & - & - & - & - & - & 0 & $E$ & - & - & - & - & - & - & - & 0 & - & - & 0 & - & $E$ & 6 \\
\hline PA36 & 0 & - & - & - & - & - & - & - & - & - & 0 & - & - & - & 0 & - & - & - & - & 0 & 0 & 5 \\
\hline PA37 & 0 & - & - & - & - & - & $E$ & 0 & - & - & - & - & - & - & - & - & - & - & - & - & - & 3 \\
\hline PA38 & 0 & - & - & - & 0 & - & 0 & 0 & 0 & - & $E$ & 0 & 0 & - & - & - & - & - & - & - & $E$ & 9 \\
\hline PA40 & $E$ & - & - & - & 0 & - & - & 0 & $E$ & - & - & - & - & - & - & - & - & - & - & - & - & 4 \\
\hline PA41 & 0 & - & - & - & - & - & - & - & - & - & 0 & - & - & - & - & - & - & - & - & - & - & 2 \\
\hline PA63 & 0 & - & - & - & - & 0 & - & 0 & - & - & - & - & - & - & - & - & - & - & - & - & - & 3 \\
\hline PA64 & 0 & - & - & - & - & 0 & - & 0 & - & - & - & - & - & - & - & $E$ & - & - & - & - & - & 4 \\
\hline PA74-1 & 0 & 0 & - & - & - & - & 0 & - & - & - & - & - & - & - & - & - & - & - & - & - & - & 2 \\
\hline PA74-2 & 0 & - & - & - & - & 0 & 0 & 0 & - & - & $E$ & - & $E$ & - & - & - & - & - & - & - & - & 6 \\
\hline PA83-1 & 0 & - & - & - & - & - & - & - & - & - & - & - & - & - & - & - & - & - & - & 0 & 0 & 3 \\
\hline PA83-2 & $E$ & 0 & 0 & - & $E$ & - & 0 & 0 & 0 & - & $E$ & 0 & 0 & - & - & $E$ & - & - & 0 & $E$ & $E$ & 14 \\
\hline PA100-1 & 0 & - & - & - & - & 0 & - & 0 & 0 & - & - & - & - & - & - & - & - & - & 0 & - & 0 & 6 \\
\hline PA100-2 & 0 & - & - & - & - & 0 & 0 & 0 & 0 & 0 & 0 & 0 & - & - & - & - & - & - & 0 & - & - & 9 \\
\hline PA101 & 0 & 0 & 0 & 0 & 0 & 0 & $E$ & $E$ & 0 & 0 & 0 & 0 & 0 & 0 & 0 & 0 & 0 & 0 & 0 & - & 0 & 20 \\
\hline IL & 28 & 4 & 4 & 4 & 6 & 13 & 18 & 20 & 11 & 2 & 16 & 5 & 5 & 1 & 4 & 5 & 4 & 1 & 8 & 4 & 12 & \\
\hline
\end{tabular}

IS the number of successful amplified species, IL the number of successful amplification primer, $O$ homozygote, $E$ heterozygote 
Table 4 Proportion of individuals of each pre-defined population in each of the $\mathbf{2}$ and $\mathbf{4}$ clusters

\begin{tabular}{|c|c|c|c|c|c|c|c|c|}
\hline & $K=2$ & & $K=4$ & & & & Subgenus & Section \\
\hline & $\begin{array}{l}\text { Composi- } \\
\text { tion } 1\end{array}$ & $\begin{array}{l}\text { Composi- } \\
\text { tion } 2\end{array}$ & $\begin{array}{l}\text { Composi- } \\
\text { tion } 1\end{array}$ & $\begin{array}{l}\text { Composi- } \\
\text { tion } 2\end{array}$ & $\begin{array}{l}\text { Composi- } \\
\text { tion } 3\end{array}$ & $\begin{array}{l}\text { Composi- } \\
\text { tion } 4\end{array}$ & & \\
\hline P. aphrodite & 0.995 & 0.005 & 0.625 & 0.371 & 0.001 & 0.002 & Phalaenopsis & Phalaenopsis \\
\hline P. amabilis & 0.689 & 0.311 & 0.572 & 0.164 & 0.238 & 0.027 & Phalaenopsis & Phalaenopsis \\
\hline P. schilleriana & 0.904 & 0.096 & 0.800 & 0.155 & 0.028 & 0.017 & Phalaenopsis & Phalaenopsis \\
\hline P. equestris & 0.988 & 0.012 & 0.824 & 0.145 & 0.003 & 0.029 & Phalaenopsis & Stauroglottis \\
\hline P.lindenii & 0.974 & 0.026 & 0.231 & 0.478 & 0.002 & 0.288 & Phalaenopsis & Stauroglottis \\
\hline P. chibae & 0.529 & 0.471 & 0.106 & 0.133 & 0.116 & 0.645 & Phalaenopsis & Deliciosae \\
\hline P.pulcherrima & 0.117 & 0.883 & 0.047 & 0.028 & 0.894 & 0.031 & Phalaenopsis & Esmeralda \\
\hline P. cornu-cervi & 0.009 & 0.991 & 0.002 & 0.002 & 0.992 & 0.004 & Polychilos & Polychilos \\
\hline P. mannii & 0.313 & 0.687 & 0.183 & 0.054 & 0.643 & 0.121 & Polychilos & Polychilos \\
\hline P. kunsteri & 0.568 & 0.432 & 0.488 & 0.111 & 0.391 & 0.01 & Polychilos & Fuscatae \\
\hline P. violacea & 0.016 & 0.984 & 0.003 & 0.002 & 0.992 & 0.003 & Polychilos & Amboinenses \\
\hline P. maculata & 0.047 & 0.953 & 0.01 & 0.012 & 0.958 & 0.02 & Polychilos & Amboinenses \\
\hline P.pulchra & 0.032 & 0.968 & 0.007 & 0.004 & 0.983 & 0.006 & Polychilos & Amboinenses \\
\hline P. micholitzii & 0.239 & 0.761 & 0.036 & 0.058 & 0.643 & 0.263 & Polychilos & Amboinenses \\
\hline P. amboinensis & 0.007 & 0.993 & 0.002 & 0.002 & 0.994 & 0.002 & Polychilos & Amboinenses \\
\hline $\begin{array}{l}\text { P. inscriptiosin- } \\
\text { ensis }\end{array}$ & 0.054 & 0.946 & 0.01 & 0.013 & 0.922 & 0.055 & Polychilos & Zebrinae \\
\hline P. corningiana & 0.028 & 0.972 & 0.003 & 0.024 & 0.859 & 0.114 & Polychilos & Zebrinae \\
\hline P. lowii & 0.214 & 0.786 & 0.063 & 0.078 & 0.815 & 0.043 & Proboscidioides & Proboscidioides \\
\hline P.parishii & 0.147 & 0.853 & 0.072 & 0.019 & 0.887 & 0.022 & Parishianae & Parishianae \\
\hline P. minnii & 0.081 & 0.919 & 0.029 & 0.008 & 0.957 & 0.006 & Aphyllae & Aphyllae \\
\hline P. braceana & 0.007 & 0.993 & 0.002 & 0.002 & 0.994 & 0.002 & Aphyllae & Aphyllae \\
\hline
\end{tabular}

Italic values indicate major component of the species

2) (Table 4). When $K=4$, Component 1 of $K=2$ was divided into three components, 1a (pink segment in Fig. 1B), 1b (orange segment in Fig. 1B), and 1c (purple segment in Fig. 1B) (Table 4). Under $K=4$, sections Deliciosae and Esmeralda can be divided into different clusters, which are grouped together when $K=4$. Two sections Phalaenopsis and Stauroglottis of subgenus Phalaenopsis were grouped together with high genetic similarity (Table 4 and Fig. 1B). In addition, section Fuscatae of subgenus Polychilos was genetically assigned to the subgenus Phalaenopsis cluster based on both section Fuscatae of subgenus Polychilos belong to pink segment group with more than $50 \%$ proportion of Component 1 (see Fig. 1A, B and Table 4). The assignment test by Bayesian clustering analysis reveals similar result with molecular phylogeny patterns described by Tsai et al. (2005). The Bayesian clustering analysis based on EST-SSR loci could not get high resolution between either subgenus or sections within subgenus (Tsai et al. 2015). Compare to EST-SSR results published by Tsai et al. (2015), these newly developed genomic microsatellite loci have higher resolution than EST-SSR loci when study on native moth orchids.

\section{Conclusions}

The Phalaenopsis species are important genetic resources for the breeding of hybrids in the horticultural market. The molecular identification markers are an important technology for breeder to improve the commercial cultivars. In this study, we developed 28 primer sets for the polymorphic microsatellite loci of Phalaenopsis aphrodite subsp. formosana, which are highly transferable among related species of the genus Phalaenopsis. Based on these transferable markers, delimitations between subgenera and between sections inferred by the Bayesian clustering analysis indicate that these SSR markers reveal 


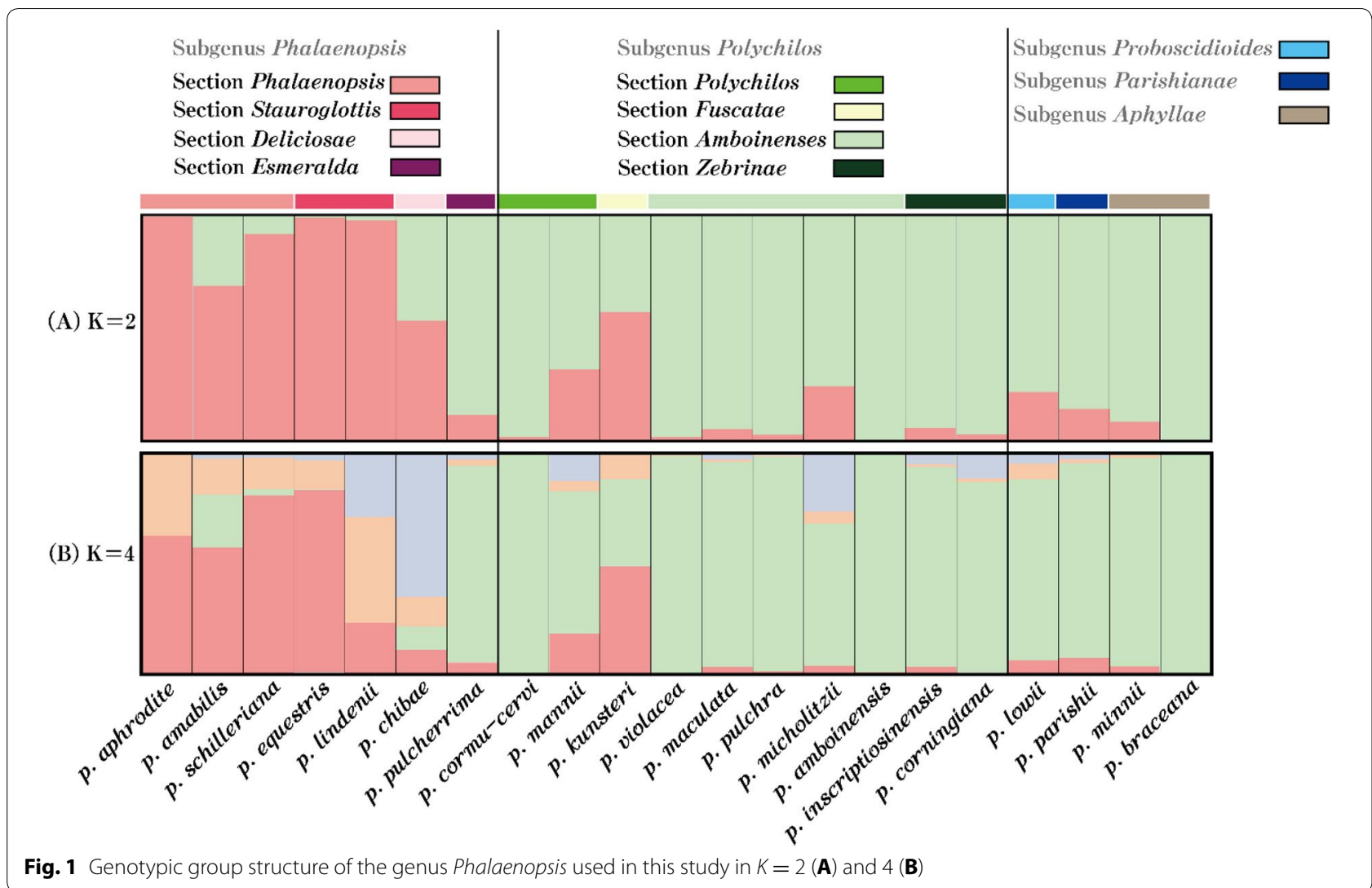

high taxonomic resolution for paternity and hybridization application among genus Phalaenopsis. In this study, we provided useful and cheap DNA barcoding markers for molecular breeding.

\section{Authors' contributions}

Conceived and designed the experiments: YZK and YCC. Performed the experiments: YZK, HCS, HHH, and YCC. Analyzed the data: YZK, HHH, and YCC. Contributed reagents/materials/analysis tools: HCS, CCT, HHH, PCL and YCC. Wrote the paper: YZK, PCL and YCC. Conceived of the study, edited the manuscript, and approved the final manuscript: $Y Z \mathrm{~K}, \mathrm{HCS}, \mathrm{CCT}, \mathrm{HHH}, \mathrm{PCL}$ and YCC. All authors read and approved the final manuscript.

\section{Author details}

1 Department of Biological Sciences, National Sun Yat-sen University, Kaohsiung 804 , Taiwan. ${ }^{2}$ Department of Nursing, Meiho University, Pingtung 912 , Taiwan. ${ }^{3}$ Kaohsiung District Agricultural Research and Extension Station, Pingtung 900, Taiwan. ${ }^{4}$ National Pingtung University of Science and Technology, Pingtung 912, Taiwan. ${ }^{5}$ Department of Life Science, National Taiwan Normal University, Taipei, Taiwan. ${ }^{6}$ Department of Biomedical Science and Environment Biology, Kaohsiung Medical University, Kaohsiung, Taiwan.

\section{Acknowledgements}

Achievement of this study is dedicated to the memory of the scientific contributions of Dr. C. C. Tsai who is the third author. Dr. C.C. Tsai dead on November 05, 2015 in an unexpected stroke. Dr. C.C. This research was supported by funding from the Ministry of Science and Technology, Taiwan, MOST 105-2621-B-110-003-MY3 and MOST 105-2621-B-110-001 to YCC and the Multidisciplinary and Data Science Research Center (MDSRC), NSYSU.

\section{Competing interests}

The authors declare that they have no competing interests.
Ethics approval and consent to participate

Not applicable.

\section{Publisher's Note}

Springer Nature remains neutral with regard to jurisdictional claims in published maps and institutional affiliations.

Received: 24 August 2017 Accepted: 4 November 2017

Published online: 15 November 2017

\section{References}

Benson G (1999) Tandem repeats finder: a program to analyze DNA sequences. Nucleic Acids Res 27(2):573-580

Chen WH, Chen HH (2007) Orchid biotechnology. World scientific Publishing Co. Ltd, Singapore

Chen WH, Chen HH (2011) Orchid biotechnology II. World scientific Publishing Co. Ltd, Singapore

Chen WH, Wang YT (1996) Phalaenopsis orchid culture. Taiwan Sugar 43:11-16 Chen WH, Kao YL, Tang CY, Tsai CC, Lin TY (2013) Estimating nuclear DNA content within 50 species of the genus Phalaenopsis Blume (Orchidaceae). Sci Hortic 161:70-75

Chiang YC, Tsai CM, Chen YKH, Lee SR, Chen CH, Lin YS, Tsai CC (2012) Development and characterization of 20 new polymorphic microsatellite markers from Mangifera indica L. (Anacardiaceae). Am J Bot 99(5):e117-e119

Chiou CY, Chiang YC, Chen CH, Yen CR, Lee SR, Lin YS, Tsai CC (2012) Development and characterization of 38 polymorphic microsatellite markers from an economical fruit tree, the Indian jujube. Am J Bot 99(5):e199-e202

Christenson EA (2001) Phalaenopsis: a monograph. Timber Press, Portland

Dressler RL (1993) Phylogeny and classification of the orchid family. Cambridge University Press, Cambridge 
Earl DA, vonHoldt BM (2012) STRUCTURE HARVESTER: a website and program for visualizing STRUCTURE output and implementing the Evanno method. Conserv Genet Resour 4:359-361

Evanno G, Regnaut S, Goudet J (2005) Detecting the number of clusters of individuals using the software structure: a simulation study. Mol Ecol 14:2611-2620

Falush D, Stephens M, Pritchard JK (2003) Inference of population structure using multilocus genotype data: linked loci and correlated allele frequencies. Genetics 164:1567-1587

Falush D, Stephens M, Pritchard JK (2007) Inference of population structure using multilocus genotype data: dominant markers and null alleles. Mo Ecol Notes 7:574-578

Hsiao YY, Pan ZJ, Hsu CC, Yang YP, Hsu YC, Chuang YC, Shih HH, Chen WH, Tsai WC, Chen HH (2011) Research on orchid biology and biotechnology. Plant Cell Physiol 52(9):467-1486

Hsu TW, Kuo CC, Tsai CC, Chiang YC (2009) Isolation and characterization of 16 microsatellite markers from a rare and endemic species, Scutellaria austrotaiwanensis (Lamiaceae). Conserv Genet Resour 1(1):85-88

Hubisz MJ, Falush D, Stephens M, Pritchard JK (2009) Inferring weak population structure with the assistance of sample group information. Mol Eco Resour 9:1322-1332

Kalendar R, Lee D, Schulman AH (2009) FastPCR software for PCR primer and probe design and repeat search. Genes Genomes Genom 3(1):1-14

Lai JM, Tsai CC, Yen CR, Ko YZ, Chen SR, Weng IS, Lin YS, Chiang YC (2015) Molecular characterization of twenty polymorphic microsatellite markers in the polyploid fruit tree species Syzygium samarangense (Myrtaceae). Genet Mol Res 14(4):13013-13021

Liu K, Muse SV (2005) PowerMarker: an integrated analysis environment for genetic marker analysis. Bioinformatics 21(9):2128-2129

Liu YC, Lin BY, Lin JY, Wu WL, Chang CC (2016) Evaluation of chloroplast DNA markers for intraspecific identification of Phalaenopsis equestris cultivars. Sci Hortic 203:86-94
Men S, Ming X, Wang Y, Liu R, Wei C, Li Y (2003) Genetic transformation of two species of orchid by biolistic bombardment. Plant Cell Rep 21(6):592-598

Powell W, Machray GC, Provan J (1996) Polymorphism revealed by simple sequence repeats. Trends Plant Sci 1(7):215-222

Pritchard JK, Stephens M, Donnelly P (2000) Inference of population structure using multilocus genotype data. Genetics 155:945-959

Rosenberg NA (2004) DISTRUCT: a program for the graphical display of population structure. Mol Ecol Notes 4:137-138

Sukma D (2011) Development of sequence-based microsatellite marker for Phalaenopsis orchid. Hayati J Biosci 18:71-76

Tanaka Y, Katsumoto Y, Brugliera F, Mason J (2005) Genetic engineering in floriculture. Plant Cell Tissue Organ Cult 80(1):1-24

Tang CY, Chen WH (2007) Breeding and development of new varieties in Phalaenopsis. In: Chen WH, Chen HH (eds) Orchids biotechnology. World Scientific Publishing Co. Pvt. Ltd, Singapore, p 1-22

Tsai CC, Huang SC, Chou CH (2005) Molecular phylogeny of Phalaenopsis Blume (Orchidaceae) based on the internal transcribed spacer of the nuclear ribosomal DNA. Plant Syst Evol 256:1-16

Tsai CC, Chiang YC, Huang SC, Chen CH, Chou CH (2010) Molecular phylogeny of Phalaenopsis Blume (Orchidaceae) on the basis of plastid and nuclear DNA. Plant Syst Evol 288(1-2):77-98

Tsai CC, Chen YKH, Chen CH, Weng IS, Tsai CM, Lee SR, Lin YS, Chiang YC (2013) Cultivar identification and genetic relationship of mango (Mangifera indica) in Taiwan using 37 SSR markers. Sci Hortic 164:196-201

Tsai CC, Wu PY, Kuo CC, Huang MC, Yu SK, Hsu TW, Chiang TY, Chiang YC (2014) Analysis of microsatellites in the vulnerable orchid Gastrodia flavilabella: the development of microsatellite markers and cross-species amplification in Gastrodia. Bot Stud 55:72

Tsai CC, Shih HC, Wang HV, Lin YS, Chang CH, Chiang YC, Chou CH (2015) RNA-seq SSRs of moth orchid and screening for molecular markers across genus Phalaenopsis (Orchidaceae). PLoS ONE 10(11):e0141761

\section{Submit your manuscript to a SpringerOpen ${ }^{\circ}$ journal and benefit from:}

- Convenient online submission

- Rigorous peer review

- Open access: articles freely available online

- High visibility within the field

- Retaining the copyright to your article

Submit your next manuscript at springeropen.com 